\title{
Dengue in the State of Rio de Janeiro, Brazil, 1986-1998
}

\author{
Rita Maria R Nogueira $/{ }^{+}$, Marize P Miagostovich, Hermann G Schatzmayr, \\ Flávia B dos Santos, Eliane S M de Araújo, Ana Maria B de Filippis, \\ Rogério V de Souza*, Sonia Maris O Zagne**, Cecília Nicolai***, \\ Mary Baran***, Gualberto Teixeira Filho****
}

Laboratório de Flavivírus, Departamento de Virologia *Hospital Evandro Chagas, Instituto Oswaldo Cruz, Av. Brasil 4365, 21045-900 Rio de Janeiro, RJ, Brasil **Departamento de Clínica Médica, Faculdade de Medicina, Universidade Federal Fluminense, Niterói, RJ, Brasil ***Secretaria Municipal de Saúde do Rio de Janeiro, RJ, Brasil ****Secretaria do Estado de Saúde do Rio de Janeiro, RJ, Brasil

This paper presents epidemiological, laboratory, and clinical data on 12 years of dengue virus activity in the State of Rio de Janeiro from the time the disease was first confirmed virologically in April 1986 through April 1998. DEN-1 and DEN-2 viruses are the serotypes circulating in the state and were responsible for the epidemics reported during the last 12 years. The results published here show both the impact of dengue virus infections on the population and laboratory advances that have improved dengue diagnosis.

Key words: dengue - epidemics - Rio de Janeiro - diagnosis

Dengue viruses occur as four antigenically related but distinct serotypes designated as DEN-1, 2, 3, and 4 (Westaway et al. 1985). They cause a broad range of disease, including clinically asymptomatic forms, classic dengue fever (characterized by sudden onset of fever, headache, retroorbital pain, and myalgia), and the more severe forms, dengue hemorrhagic fever/dengue shock syndrome (DHF/DSS).

Dengue was first recognized in the State of Rio de Janeiro some 70 years ago, when Antônio Pedro described a disease clinically similar to dengue fever in the city of Niterói (Pedro 1923). No dengue cases were reported for the following 63 years; Ae. aegypti, the principal mosquito vector, was eradicated by Brazilian health authorities in the 1950s.

Ae. aegypti was detected in the state again in 1977 , and by the 1980s several municipalities presented high infestation rates. Reintroduction of the dengue virus in 1986 launched a period of intense dengue activity in the state with an enormous impact on the population.

The State of Rio de Janeiro, with 13,216,835 inhabitants, is divided politically and administra-

\footnotetext{
Supported by CNPq, Fundação Banco do Brasil, Fundação Nacional de Saúde and IDRC, Canada. ${ }^{+}$Corresponding author. Fax: + 55-21-270.6397. E-mail: rita@gene.dbbm.fiocruz.br Received 19 August 1998 Accepted 14 December 1998
}

tively into 91 municipalities (counties), arranged in eight regions with specific climatic and geographic features: Greater Metropolitan Rio de Janeiro, Northwest, North, Mountains, Coastal Lowlands, Middle Paraíba Valley, Central-South, and Ilha Grande Bay (Fig. 1). The Greater Metropolitan Area, with some $10,000,000$ inhabitants, includes the capital of the state, Rio de Janeiro, and 16 other municipalities and has been the most heavily affected area by dengue outbreaks. During the last 12 years the state has reported four epidemics with a total of 400,000 reported cases (Secretary of Health of the State of Rio de Janeiro 1998).

Dengue virus epidemiology in the State of Rio de Janeiro - Dengue infection was first confirmed by laboratory in the State of Rio de Janeiro in April 1986, when the DEN-1 virus was isolated during an outbreak of exanthematic disease in the city of Nova Iguaçu (Schatzmayr et al. 1986). Nova Iguaçu, part of Greater Metropolitan Rio de Janeiro, has many small-scale industries and scrap metal yards with numerous mosquito breeding sites. In 1986, Nova Iguaçu had household infestation rates for the Ae. aegypti vector as high as $28 \%$ in some neighborhoods (Secretary of Health of the State of Rio de Janeiro 1998). It is a low-income suburban city located some $25 \mathrm{~km}$ from downtown Rio de Janeiro, with a large population contingent that commutes daily to surrounding areas. This heavy circulation of human beings facilitated the rapid spread of DEN-1 virus to susceptible populations of Rio de Janeiro and other neighboring cities in the Greater Metropolitan Area, like Nilópolis, São João de Meriti, 


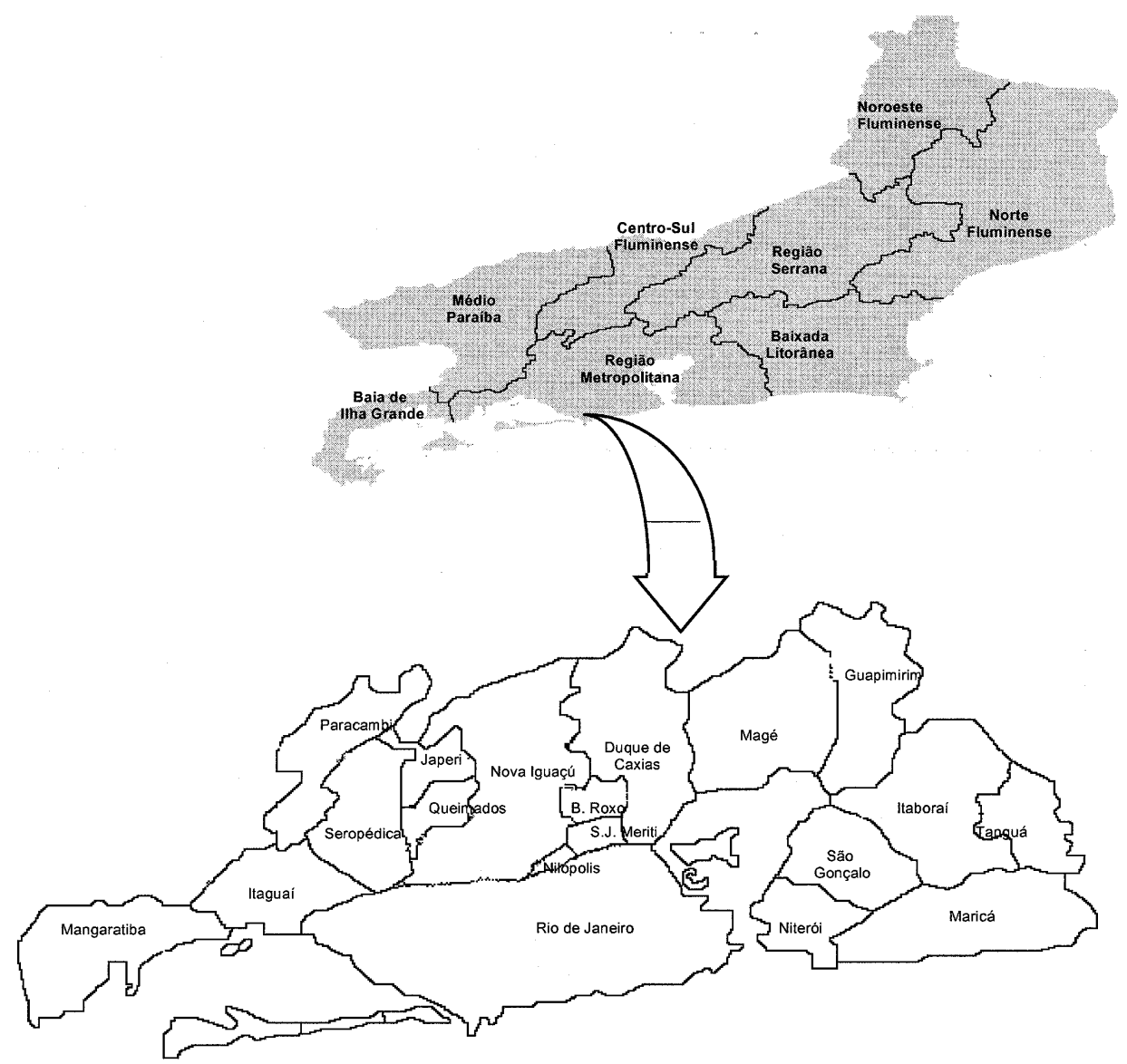

Fig. 1: politic administrative division of the State of Rio de Janeiro.

Niterói, and Duque de Caxias, causing an explosive epidemic with 95,000 cases reported during the 1986-1987 period. Underreporting of cases, due to lack of knowledge concerning the disease, was demonstrated by serological surveys performed in several municipalities after the epidemic, with an estimated real occurrence of $3,000,000$ cases of infection since the first reports (Figueiredo et al. 1990).

The 1988-89 period was characterized by low dengue virus activity. Only three DEN-1 viruses had been isolated by November 1989, when increased DEN-1 activity was noted and a new epidemic was recognized.

In April 1990, during a period of high DEN-1 virus activity, a new virus serotype, DEN-2, was isolated in the city of Niterói, exactly four years after the DEN-1 virus was first isolated (Nogueira et al. 1990). Simultaneous circulation of DEN-1 and DEN-2 viruses characterized the largest dengue epidemic (1990-1991) reported in the state, with a total of 140,000 reported cases (Secretary of Health of the State of Rio de Janeiro 1998).
During this epidemic (1990-1991) DHF/DSS case due to DEN-2 virus with a fatal outcome was reported in Niterói. The patient had a prior history of dengue fever in 1987 confirmed by an IgG Elisa titer of 1/256,000 for anti-DEN-1 (Nogueira et al. 1991).

A period of low dengue virus activity characterized the period from 1992 to 1994, when 2,568 cases were reported in the state. Only 7 out of 304 reported cases that were submitted for laboratory investigation were confirmed by serology.

A new epidemic recognized in 1995 , extended into the following year, with a total of 50,000 reported cases of dengue fever. Both the DEN-1 and DEN-2 serotypes were isolated during this period.

Only 1,361 dengue cases were reported in 1997. However, in January 1998 a new epidemic broke out in the Middle Paraíba Region, mainly affecting the municipalities of Pinheiral, Barra do Piraí, Barra Mansa, and Volta Redonda. The epidemic quickly spread to other municipalities in the state and soon reached an important tourist area on the northern coast of the state, including the towns of 
Búzios, Araruama, and Iguaba. DEN-1 virus was the only serotype isolated in the state until March, when the DEN-2 virus was isolated in the cities of Rio de Janeiro and Niterói. As of the 14th epidemiological week of 1998, 15,727 cases had been reported in the state.

As observed in Fig. 2, the municipality of Rio de Janeiro has been responsible for most of the reported dengue cases, although 81 out of 91 municipalities in the state have already reported dengue outbreaks during the last 12 years.

Fig. 3 shows the monthly accumulated number of reported cases from April 1986 to April 1998 and the periodicity of epidemics in the state. Dur- ing this period the four largest epidemics occurred during summer months.

Co-circulation of the two serotypes in the state showed that successive infections increased the appearance of more severe clinical presentations, as demonstrated by the number of DHF/DSS cases reported after introduction of the DEN-2 virus (Table I). A predominance of DEN-2 virus isolation from August 1990 to 1991 was associated with more hospitalizations (Nogueira et al. 1993). The maximum number of DHF/DSS cases reported during the peak month of dengue fever supports the iceberg theory of DHF/DSS (Gubler 1988, 1993).

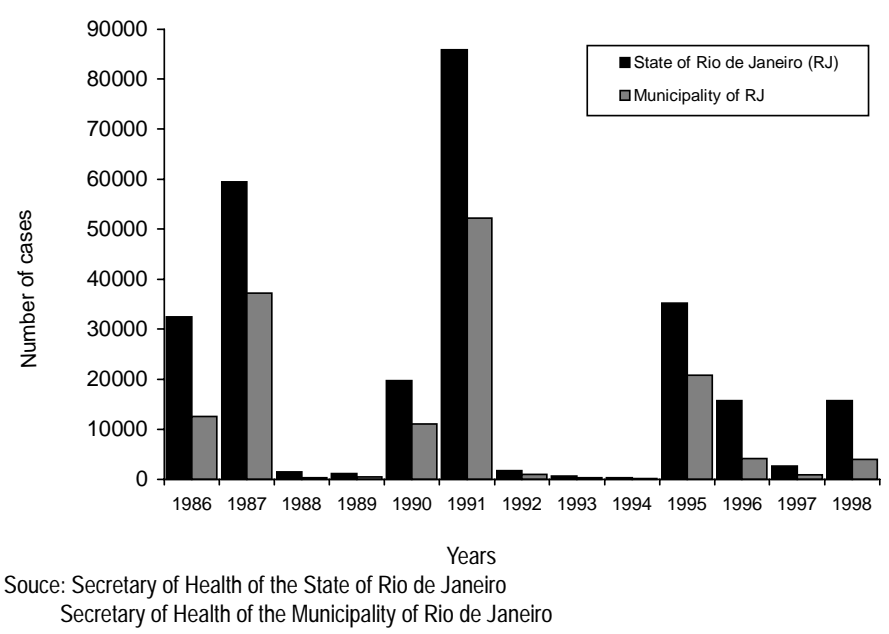

Fig. 2: dengue reported cases in the State of Rio de Janeiro from April 1986 to April 1998.

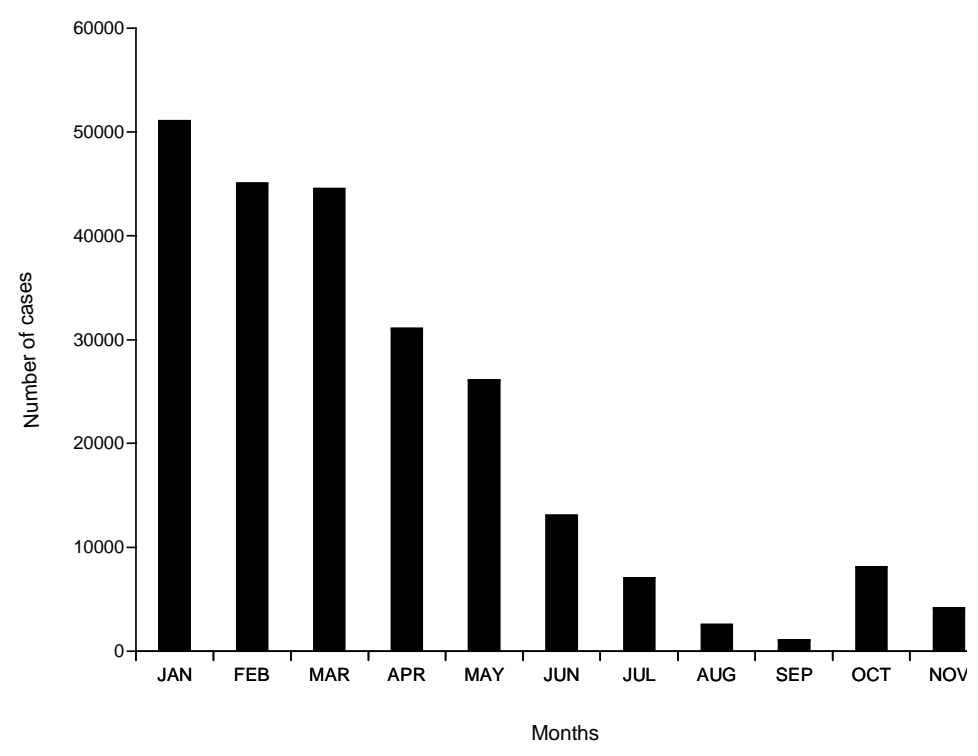

Souce: Secretary of Health of the State of Rio de Janeiro

Fig. 3: cumulative cases of dengue by month in the State of Rio de Janeiro from April 1986 to April 1998. 
TABLE I

Notified dengue haemorrhagic fever/dengue shock syndrome in the State of Rio de Janeiro, 1990-1998

\begin{tabular}{|c|c|c|c|c|c|c|c|c|c|c|c|c|c|}
\hline & Jan & Feb & Mar & Apr & May & Jun & Jul & Aug & Sep & Oct & Nov & Dec & Total \\
\hline 1990 & - & - & - & 2 & 2 & 10 & 7 & 5 & 1 & 3 & 29 & 161 & 220 \\
\hline 1991 & 565 & 261 & 145 & 85 & 26 & 1 & 1 & - & 1 & - & 1 & - & 1,086 \\
\hline 1995 & 3 & 57 & 51 & 9 & 11 & 2 & - & - & 1 & 3 & 1 & - & 138 \\
\hline 1996 & 1 & 2 & 12 & 26 & 20 & 1 & - & 1 & - & - & - & - & 63 \\
\hline 1997 & 2 & 4 & 3 & 3 & 1 & - & - & - & - & 1 & - & 2 & 16 \\
\hline $1998^{a}$ & 1 & 2 & 3 & 13 & - & - & - & - & - & - & - & - & 19 \\
\hline
\end{tabular}

$a$ : cases reported until April 1998; Source: Secretary of Health of the State of Rio de Janeiro.

Clinical findings - During the 1986-1987 period, dengue infection presented as a classic dengue fever epidemic. However, a few cases of severe disease were observed. DEN-1 virus was isolated from the liver of a 17-year-old male (Nogueira et al. 1988), and five other fatal dengue cases with involvement of the central nervous system (CNS) were reported (Chimelli et al. 1990).

The subsequent epidemics displayed the same classic dengue fever profile observed in 1986. Fig. 4 shows the signs and symptoms of classic dengue fever observed during two epidemics (1986-1987 and 1995-1996). The introduction of DEN-2 virus increased the number of severe disease cases with the appearance of several cases of DHF/DSS. Signs and symptoms of these cases were described by Zagne et al. (1994).

Laboratory confirmation - Suspected dengue cases were confirmed by an IgM capture enzymelinked immunosorbent assay (Mac-Elisa) described by Kuno et al. (1987), and/or by virus isolation in cell cultures of Ae. albopictus clone C6/36 (Igarashi 1978). Table II shows the laboratory diagnosis from serum samples collected from 15,219 patients during epidemic periods. All procedures were performed at the Flavivirus Laboratory, Oswaldo Cruz Institute/Fiocruz.

Mac-Elisa was employed for the first time on a large scale in 1986 and made it possible to determine IgM antibody levels in the population without prior exposure to dengue virus (Nogueira et al. 1992). After introduction of the DEN-2 virus, a mixture of DEN-1 and DEN-2 antigens was employed, and this assay proved to be useful for detecting $\operatorname{IgM}$ in the secondary immune response (Nogueira et al. 1993).

Dengue virus isolates were identified by using dengue monoclonal antibodies as described by Gubler et al. (1984). During the first epidemic period (1986-1987), a high percentage (41.2\%) of

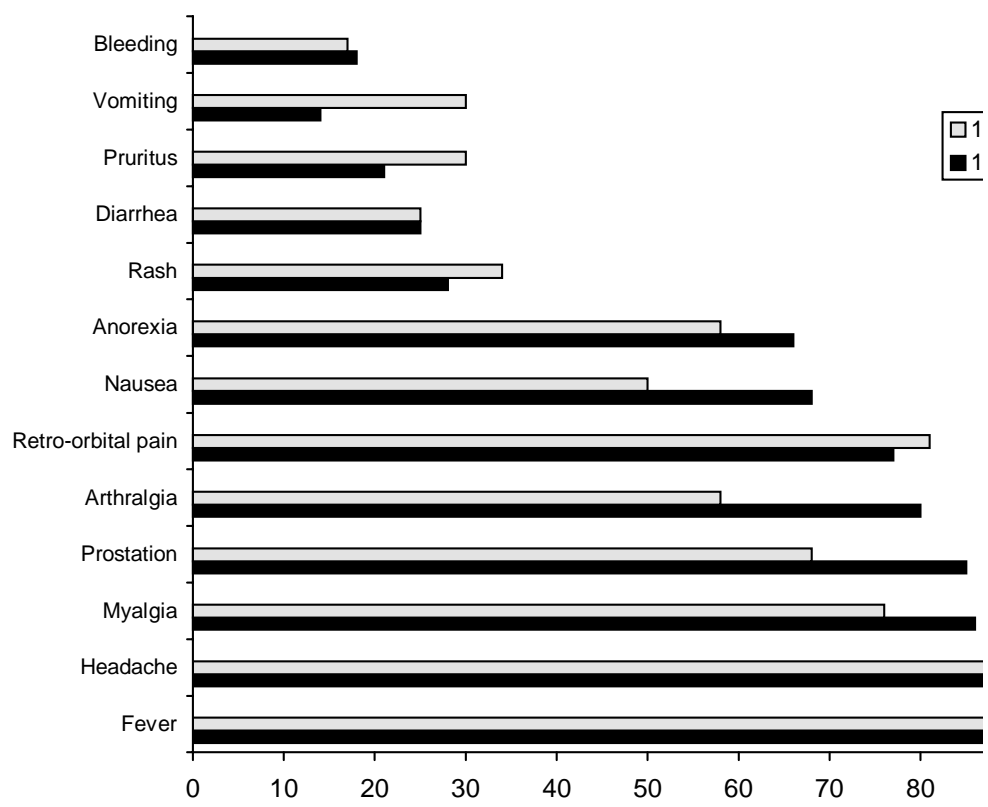

Fig. 4: signs and symptoms of 250 laboratorial confirmed dengue fever in the State of Rio de Janeiro during different periods. 
TABLE II

Laboratorial diagnosis of dengue in the State of Rio de Janeiro: April 1986 - April 1998

\begin{tabular}{lccc}
\hline Years & Dengue serotypes & \% of virus isolation & $\begin{array}{c}\text { Total of confirmed cases by } \\
\text { virus isolation and/or serology }\end{array}$ \\
\hline $1986-87$ & DEN-1 (1039) & $1,039 / 2,520$ & $1,874 / 3,178$ \\
$1990-91$ & $(41.2 \%)$ & $(59 \%)$ \\
& DEN-1 (225) & $413 / 2,474$ & $2,109 / 5,964$ \\
$1995-96$ & DEN-2 (188) & $(16.7 \%)$ & $(35.4 \%)$ \\
& DEN-1 (37) & $132 / 1,353$ & $921 / 3,494$ \\
1998 & DEN-2 (95) & $(9.8 \%)$ & $(26.4 \%)$ \\
& DEN-1 (156) & $158 / 865$ & $(19.6 \%)$ \\
\hline
\end{tabular}

DEN-1 virus isolation was achieved, however a clear downward trend in the virus isolation rate has been observed over the years. However, in 1998 new areas in the state where dengue activity is characterized as a virgin epidemic, like Pinheiral (Middle Paraíba Valley), showed a 33.6\% DEN-1 virus isolation rate $(81 / 160)$.

The Flavivirus Laboratory has introduced new methodologies since 1995 in order to improve dengue diagnosis. The method employing reverse transcription followed by polymerase chain reaction (RT-PCR) described by Lanciotti et al. (1992) was employed during the 1995-1996 epidemic for rapid dengue virus identification. RT-PCR from clinical samples identified DEN-1 and DEN-2 in 41\% (41/ 100) of cases previously confirmed by serology where no virus isolation was achieved and proved to be an applicable method for retrospective dengue diagnosis, especially in fatal cases. In addition, it is rapidly becoming useful for monitoring dengue virus activity in new areas of the state (Miagostovich et al. 1997b). Other RT-PCR protocols have also supported molecular epidemiological studies conducted over the years. Analysis of DEN-1 and DEN-2 viruses isolated in the state using endonuclease enzyme restriction and partial genome sequencing showed that the viruses belong to the Caribbean and Jamaican genotypes, respectively (Rico-Hesse 1990, Deubel et al. 1993, Lewis et al. 1993, Vorndam et al. 1994, Miagostovich et al. 1998).

During the same period, serum specimens previously screened by Mac-Elisa were also used to characterize the immune response analyzed by IgGElisa. The high sensitivity and specificity of IgGElisa support the use of an association of $\operatorname{IgM}$ and IgG Elisa tests to perform rapid dengue diagnosis and classify the immune response, especially in severe disease, to evaluate the role of sequential infection (Miagostovich, unpublished data).
In a retrospective study, the use of the immunohistochemical procedure confirmed dengue infection in five fatal cases previously described by Chimelli et al. (1990). All of these cases were associated with encephalopathy, and in three of them dengue virus antigen was demonstrated in the CNS. Extended immunohistochemical studies performed in one case demonstrated infiltration of CD68+ macrophages by the breakdown of the blood-brain barrier, showing that virus-infected macrophages could be one of the pathways by which virus enters the brain. Dengue virus antigen was also detected in hepatocytes and in the cytoplasm of phagocytic mononuclear cells from the liver, spleen, and lung (Miagostovich et al. 1997a).

\section{DISCUSSION}

The Greater Rio de Janeiro Metropolitan Area has the largest population and labor force in the state. Most of the state's industry is located in this region, constituting a highly diversified industrial complex. Eighty percent of the state's population is concentrated in the Greater Metropolitan Area, causing intense social conflict and pressure, since economic growth has not achieved the expected results. Major problems include the lack of urban services and infrastructure, an increasing housing deficit, marked by the spread of substandard housing and slum areas, and environmental degradation. All these factors have contributed to the Greater Metropolitan Area's high percentage of total dengue cases reported in the state. During recent years, the only municipalities that have not reported authoctone dengue cases were from the Mountain Region.

Transmission of dengue virus by the Ae. aegypti was demonstrated by dengue virus isolation from a vector pool during the 1986 epidemic (Nogueira et al. 1988). Although Ae. albopictus has been present in the State of Rio de Janeiro since 1986, 
there is no evidence for transmission of dengue by this mosquito species in the state.

The city of Rio de Janeiro is very important as a tourist center, mainly during summer months, thus explaining the rapid spread of DEN-1 and DEN-2 viruses to other states of Brazil in 1986 and 1990, respectively. Virus dispersion occurred along major highways that link the State of Rio de Janeiro to various other urban areas of the country. Twenty out of 26 Brazilian's states have already reported dengue epidemics, of which 16 presented co-circulation of two serotypes (Brazilian Ministry of Health). The State of Rio de Janeiro has been responsible for a high percentage of all dengue cases reported in Brazil, mainly during epidemic periods: e.g., 67.2\% (1986-1987), 76.5\% (1990-1991), and $17.4 \%$ (1995-1996).

The endemicity of dengue viruses in Brazil is a major concern, since two serotypes are now widespread. Several states have reported an increase in DHF/DSS cases since 1990, when the DEN-2 virus was introduced into the country (Nogueira et al. 1993, Zagne et al. 1994, Souza et al. 1995, Vasconcelos et al. 1995). Co-circulation of multiple serotypes has been associated with DHF/DSS in Southeast Asia (Halstead et al. 1967, Gubler 1993). DEN-2 infection following a DEN-1 epidemic has also been suggested as an important factor in the emergence of more severe forms of infection (Guzman et al. 1986, Halstead 1970, Thein et al. 1997).

During the 1990-1991 epidemic in the State of Rio de Janeiro, a study of 56 well-documented cases of DHF/DSS demonstrated a predominant involvement of adults with secondary infection (Zagne et al. 1994). The lack of DHF/DSS in children with secondary infection was also demonstrated during a serological survey conducted in the municipality of Niterói (Cunha et al. 1995).

A high proportion of DHF/DSS in adults was also observed in many countries of the Americas (Gubler 1993). This disease pattern is quite different from that of Southeast Asia, where 95\% of DHF/DSS cases occurred in children under 15 years of age (Knudsen 1996). The lower endemicity of dengue viruses in the Americas as compared to Southeast Asia, where large dengue epidemics with DHF/DSS have occurred since the 1950s, has resulted in a large number of adults susceptible to dengue infection, which could explain this observation.

According to the World Health Organization, DHF/DSS has four major clinical signs: high fever, hemorrhagic manifestations, hepatomegaly, and circulatory failure. The laboratory profile is characterized by thrombocytopenia and hemoconcentration (WHO 1986). In the State of Rio de
Janeiro, difficulties in performing routine hematocrits and platelet counts, along with the rigidity of these criteria, resulted in the non-characterization of various cases of DHF stages I and II. This fact is likely responsible for the high dengue case fatality rate not only in the State of Rio de Janeiro but in Brazil as a whole.

Clinical aspects of dengue surveillance emphasize the importance of differential diagnosis, including not only exanthematic diseases like rubella, measles, and enteroviruses (Morens et al. 1978, 1986), but also non-exanthematic diseases. For instance, during 1986 some suspected dengue cases with negative dengue serology were confirmed serologically as influenza A (H3N2) and others as influenza B. That same year the influenza virus was isolated in Rio de Janeiro between July and August (Nascimento \& Nogueira 1992).

Different patterns of clinical manifestations for dengue infection, like viral hepatitis and encephalitis, should be also taken in account, since liver and brain involvement have been demonstrated in dengue infection (Lum et al. 1993, 1996, Patey et al. 1993, Dietz et al. 1996, Row et al. 1996, Nguyen et al. 1997). In the State of Rio de Janeiro, liver involvement was recorded by elevation of aminotransferases in 35 cases of DHF/DSS (Zagne et al. 1998) and brain involvement demonstrated as previously described (Miagostovich et al. 1997a).

Another aspect to be considered in dengue surveillance is the gathering of clinical samples. During a period of low activity, it is very difficult to obtain serum samples from febrile disease in order to conduct active surveillance. On the other hand, during epidemic periods, collecting too many serum samples in the same area causes a delay in laboratory processing and may hinder investigation of samples from severe cases and those collected in areas where the virus has been introduced recently. Improper processing and handling of samples is also troublesome. It is essential to provide clear-cut guidelines for collecting and transporting samples for laboratory diagnosis of dengue, including autopsy specimens.

The risk of introduction of new serotypes into Brazil poses an additional threat for developing DHF/DSS. DEN-4 virus is endemic in countries bordering on Brazil, like Venezuela and Colombia, and the DEN-3 virus, reintroduced into the Americas in 1994, has been isolated in Nicaragua, Panama, Mexico, Costa Rica, Guatemala, Belize, El Salvador, Honduras, and Puerto Rico. The strains of DEN-3 isolated in the Americas belong to the Sri Lanka genotype, the cause of major epidemics in India and Sri Lanka (Anonymous 1995). DEN-3 and DEN-4 viruses are potential agents for 
new and extensive epidemics in Brazil considering the large population of individuals susceptible to both serotypes, and their circulation could characterize a hyperendemic profile for the country.

There is an obvious need to detect the initial dengue cases before a major outbreak develops, and active epidemiological surveillance backed by laboratory diagnosis is the only way to detect the introduction of new serotypes or genotypes of dengue into an area. Development of new assays is an important tool to help quell the spread of dengue virus activity, since the association of different methodologies increases the number of confirmed cases.

Since Rio de Janeiro is a large port city with a major human contingent circulating through its international airport, it has been the port of entry for dengue viruses into Brazil, therefore meriting close attention by the state's epidemiological surveillance system.

\section{ACKNOWLEDGMENTS}

To José de Carvalho Filho, José da Costa Farias Filho, Bruna Fernandes Esteves and Cláudia Ferro Nazareno for technical assistance.

\section{REFERENCES}

Anonymous 1995. Dengue 3 in Central America. Dengue Surveillance Summary. Dengue Branch, San Juan, Puerto Rico. Division of Vector-Borne Infectious Diseases, CDC, $70 \mathrm{pp}$.

Chimelli L, Dumas Hahn M, Barreto Neto M, Grandelle Ramos R, Dias M, Gray F 1990. Dengue: neuropathological findings in five fatal cases from Brazil. Clin Neuropath 9: 157-162.

Cunha RV, Dias M, Nogueira RMR, Chagas N, Miagostovich MP, Schatzmayr HG 1995. Secondary dengue infection in schoolchildren in a dengue endemic area in the State of Rio de Janeiro. Rev Inst Med Trop São Paulo 37: 517-521.

Deubel V, Nogueira RMR, Drouet MT, Zeller M, Reynes J, Ma DQ 1993. Direct sequencing of genomic cDNA fragment amplified by the polymerase chain reaction for molecular epidemiology of dengue 2 viruses. Arch Virol 129: 197-210.

Dietz V, Gubler DJ, Ortiz S, Casta Vélez A, Sather GE, Gómez I, Vergne E 1996. The 1986 dengue and dengue hemorrhagic fever epidemic in Puerto Rico: epidemiologic and clinical observations. P R Health Sci J 15: 201-210.

Figueiredo LTM, Cavalcante SMB, Simões MC 1990. Dengue serologic survey of school children in Rio de Janeiro, Brazil, 1986 and 1987. Bull PAHO 24: 217225.

Gubler DJ 1988. Dengue, p. 223-60. In TP Monath, The Arboviruses: Epidemiology and Ecology, CRC Press, Boca Raton, FL.

Gubler DJ 1993. Dengue and dengue haemorrhagic fever in the Americas, p. 9-22. In World Health Organization, Regional Office for Southeast Asia, New Deli. Monograph on dengue/dengue haemorrhagic fever.
Regional Publication, SEARO no. 22.

Gubler DJ, Kuno G, Sather GE, Velez M, Oliver A 1984. Use of mosquito cell cultures and specific monoclonal antibodies in surveillance for dengue viruses. Am J Trop Med Hyg 33: 158-165.

Guzman MG, Kourí G, Bravo J 1986. Is sequential infection a risk factor for DHF/DSS? Arthropodborne Virus Information Exchange, 172-175.

Halstead SB, Nimmannitya S, Cohen SN 1970. Observations related to pathogenesis of dengue hemorrhagic fever. IV. Relation of disease severity to antibody response and virus recovered. Yale J Biol Med 42: 311-328.

Halstead SB, Nimmannitya S, Yamarat C, Russel PK 1967. Hemorrhagic fever in Thailand; newer knowledge regarding etiology. Jpn J Med Sci Biol 20: 96-103.

Igarashi A 1978. Isolation of a Singh's Aedes albopictus cell clone sensitive to dengue and chikungunya viruses. J Gen Virol 40: 531-544.

Kuno G, Gomez I, Gubler DJ 1987. Detecting artificial anti-dengue $\mathrm{IgM}$ immune complexes using an enzyme-linked immunosorbent assay. Am J Trop Med Hyg 36: 153-159.

Knudsen AB 1996. Global strategy for the prevention and control of dengue and dengue haemorrhagic fever, p. 27. In International Seminar on Dengue, Rio de Janeiro.

Lanciotti RS, Calisher CH, Gubler DJ, Chang GJ, Vorndam V 1992. Rapid detection and typing of dengue viruses from clinical samples by using reverse transcriptase-polymerase chain reaction. $J$ Clin Microbiol 30: 545-551.

Lewis JA, Chang GJ, Lanciotti RS, Kinney RM, Mayer LW, Trent DT 1993. Philogenetic relationship of dengue-2 viruses. Virology 197: 216-224.

Lum LC, Lam SK, Choy YS, George R, Harun F 1996. Dengue encephalitis - a true entity? Am J Trop Med Hyg 54: 256-259.

Lum LC, Lam SK, George R, Devi S 1993. Fulminant hepatitis in dengue infection. Southeast Asian J Trop Med Public Hlth 24: 467-471.

Miagostovich MP, Nogueira RMR, Schatzmayr HG, Lanciotti RS 1998. Molecular epidemiology of DEN-2 virus in Brazil. Mem Inst Oswaldo Cruz 93: 625-626.

Miagostovich MP, Ramos RG, Nicol AF, Nogueira RMR, Cuzzi-Maya T, Oliveira AV, Marchevsky RS, Mesquita RP, Schatzmayr HG 1997a. Retrospective study on dengue fatal cases. Clinical Neuropathol 16: 204-208.

Miagostovich MP, Santos FB, Araújo ESM, Dias J, Schatzmayr HG, Nogueira RMR 1997b. Diagnosis of dengue by using reverse transcriptase polymerase chain reaction. Mem Inst Oswaldo Cruz 92: 595-600.

Morens DM, Woodall JP, Lopez-Correa RH 1978. Dengue in American children of the Caribbean. $J$ Pediatr 93: 1049-1051.

Morens DM, Rigau-Perez JG, Lopez-Correa RH, Moore CG, Ruiz-Tiben EE, Sather GE, Chiriboga J, Erliason DA, Casta Velez A, Woodall JP 1986. 
Dengue outbreak investigation group dengue in Puerto Rico, 1977: Public Health response to characterize and control an epidemic of multiple serotypes. Am J Trop Med Hyg 35: 197-211.

Nascimento JP, Nogueira RMR 1992. An International Scientific Conference. Option for the Control of Influenza. France.

Nguyen TL, Nguyen TH, Tieu NT 1997. The impact of dengue haemorrhagic fever on liver function. Res Virol 148: 273-277.

Nogueira RMR, Miagostovich MP, Cavalcanti SMB, Marzochi KBF, Schatzmayr HG 1992. Levels of IgM antibodies against dengue virus in Rio de Janeiro, Brazil. Res Virol 143: 423-427.

Nogueira RMR, Miagostovich MP, Lampe E, Schatzmayr HG 1990. Isolation of dengue virus type 2 in Rio de Janeiro. Mem Inst Oswaldo Cruz 85: 253.

Nogueira RMR, Miagostovich MP, Lampe E, Souza RW, Zagne SMO, Schatzmayr HG 1993. Dengue epidemic in the State of Rio de Janeiro, Brazil, 19901991: co-circulation of dengue 1 and dengue 2 serotypes. Epidemiol Infect 111: 163-170.

Nogueira RMR, Schatzmayr HG, Miagostovich MP, Farias MFDB, Farias Filho JC 1988. Virological study of dengue type 1 epidemic at Rio de Janeiro. Mem Inst Oswaldo Cruz 83: 219-225.

Nogueira RMR, Zagne SMO, Martins ISM, Lampe E, Miagostovich MP, Schatzmayr HG 1991. Dengue haemorrhagic fever/dengue shock syndrome (DHF/ DSS) caused by serotype 2 in Brazil. Mem Inst Oswaldo Cruz 86: 269.

Patey O, Ollivaud L, Breuil J, Lafaix C 1993. Unusual neurological manifestations occurring during dengue fever infection. Am J Trop Med Hyg 48: 793-802.

Pedro A 1923. O Dengue em Nictheroy. Brazil-Med 1: 173-177.

Rico-Hesse R 1990. Molecular evolution and distribution of dengue viruses type 1 and 2 in nature. Virology 174: 479-493.

Row D, Weistein P, Murray-Smith S 1996. Dengue fever with encephalopathy in Australia. Am J Trop Med
Hyg $54: 253-255$.

Schatzmayr HG, Nogueira RMR, Travassos Da Rosa APA 1986. An outbreak of dengue virus at Rio de Janeiro - 1986. Mem Inst Oswaldo Cruz 81: 245-246.

Secretary of Health of the State of Rio de Janeiro 1998. Statistical report of Diseases transmitted by Vectors and Zoonosis. Trimestral Report.

Souza RV, Cunha RV, Miagostovich MP, Timbó MJ, Montenegro F, Pessoa ETFP, Nogueira RMR, Schatzmayr HG 1995. An outbreak of dengue in the State of Ceará, Brazil. Mem Inst Oswaldo Cruz 90: 345-346.

Thein S, Aung MM, Shwe TN, Aye M, Zaw A, Aye K, Aye KM, Aaskov J 1997. Risk factors in dengue shock syndrome. Am J Trop Med Hyg 56: 566-572.

Vasconcelos PFC, Menezes DB, Melo LP, Paula Pessoa ETF, Rodrigues SG, Travassos Da Rosa ES, Timbó MJ, Coelho ICB, Montenegro F, Travassos Da Rosa JFS, Andrade FMO, Travassos Da Rosa APA 1995. A large epidemic of dengue fever with dengue hemorrhagic cases in Ceará State, Brazil, 1994. Rev Inst Med Trop São Paulo 37: 253-255.

Vorndam V, Nogueira RMR, Trent DW 1994. Restriction enzymes analysis of American region dengue viruses. Arch Virol 136: 191-196.

Westaway EG, Brinton MA, Gaidamovich Sya, Horzinek MC, Igarashi A, Kaariainen L, Lvov DK, Porterfield JE, Russell PK, Trent DW 1985. Flaviviridae. Intervirology 24: 183-192.

WHO - World Health Organization 1986. Dengue haemorrhagic fever: diagnostic, treatment and control, $58 \mathrm{pp}$.

Zagne SMO, Alves VGF, Nogueira RMR, Miagostovich MP, Lampe E, Tavares W 1994. Dengue haemorrhagic fever in the State of Rio de Janeiro, Brazil: a study of 56 confirmed cases. Trans $R$ Soc Trop Med Hyg 88: 677-679.

Zagne SMO, Santana RS, Hoffmamm LMA, Miagostovich MP, Nogueira RMR 1998. Dengue hemorrágico: alterações de provas de função hepática. Rev Soc Bras Med Trop (Supl. 1) 31: 129. 